The Chittagong Univ. J. B. Sci., Vol. 6(1 \&2):187-197, 2011.

\title{
SOIL FERTILITY STATUS OF SOME MANGO ORCHARDS IN CHITTAGONG HILL TRACTS
}

\author{
M. G. KIBRIA ${ }^{1}$, M. J. AHAMMAD ${ }^{1}$ AND K. T. OSMAN ${ }^{1 *}$ \\ Department of Soil Science, University of Chittagong, Chittagong 4331, Bangladesh
}

\begin{abstract}
Major physico-chemical properties of mango orchard soils (Mangifera indica L.) in different sites of three hill districts, Rangamati, Khagrachari and Bandarban were evaluated. Soils were sandy loam in texture at all the sites except foot hill soil of Shapchari. Soil $\mathrm{pH}$, organic matter, total $\mathrm{N}$ and available $\mathrm{P}$ varied from 4.76 to $5.58,1.43$ to $2.49 \%, 0.10$ to $0.16 \%, 0.86 \mathrm{mg} \mathrm{kg}^{-1}$ to $2.69 \mathrm{mg} \mathrm{kg}^{-1}$ soil, respectively in surface soil of different sites of mango orchard. $1 \mathrm{~N} \mathrm{NH}_{4} \mathrm{OAc}$ extractable $\mathrm{K}^{+}, \mathrm{Ca}^{2+}$ and $\mathrm{Mg}^{2+}$ ranged from 0.35 to $0.82,2.50$ to 3.66 and 0.60 to $1.57 \mathrm{cmol} \mathrm{kg}^{-1}$ of soils. Soil $\mathrm{pH}$, organic matter, total $\mathrm{N}$ and available $\mathrm{P}$ varied significantly among the slope positions within the sites. Similar results were found in case of $1 \mathrm{~N} \mathrm{NH} \mathrm{NHAc}_{4}$ extractable $\mathrm{K}^{+}, \mathrm{Ca}^{2+}$ and $\mathrm{Mg}^{2+}$. The soils are generally poor in organic matter and nutrients.
\end{abstract}

Key words: Mango orchard, Organic matter, Total nitrogen, Available phosphorus.

\section{INTRODUCTION}

Today fruits are cultivated frequently in the hilly and mountainous regions of the world (Gautam et al. 2004). Fruits are also grown in the hills of Bangladesh. Chittagong Hill Tracts (CHT) lies in southeastern part of the country $\left(21^{\circ} 25^{\prime} \mathrm{N}\right.$ to $23^{\circ} 45^{\prime} \mathrm{N}$ latitude and $91^{\circ} 54^{\prime} \mathrm{E}$ to $92^{\circ} 50^{\prime} \mathrm{E}$ longitude). The CHT region constitutes $76 \%$ of the total hilly region of Bangladesh (about 13,184sq $\mathrm{km}$ ), of which $90 \%$ of the area is hilly, $4 \%$ covers villages, rivers and marshes and $6 \%$ only suitable for intensive agriculture (Khisa 1997). Orchard fruit production comprises the largest fruit sector in south-eastern part of Bangladesh. The potential for these orchards to alleviate poverty in marginal farming areas is well appreciated, but low yields and poor fruit quality are major hurdles to overcome for a large number of production areas. Soil fertility may have a significant role on its growth and production. Plant growth, productivity and eminence are closely related to nutrient concentrations of plants. For optimum fruit production, nutrient concentrations should be at sufficient level in plants. Factors relevant to nutrient

\footnotetext{
*Corresponding author:ktosmancu@gmail.com
} 
availability to plants are mainly governed by soil fertility status (Marschner, 1995). Macronutrients play an important role in the growth and development of the orchard crop. One of the major efforts towards improving fruit yields and quality is the identification and correction of critical soil fertility factors. Mango is one of the major fruit crops grown in Bangladesh. The total production of mango in Bangladesh was recorded to be 187, $000 \mathrm{~m}$ tons during 2001-2002 from an area of 50600 hectares of land (BBS 2009). Mango is being cultivated in considerable areas of hill tracts. The present research work has been undertaken to evaluate fertility status of mango orchard soil in CHT of Bangladesh.

\section{MATERIALS AND METHODS}

\section{Study area}

The study area covered mainly three hilly districts, Rangamati, Khagrachari and Bandarban of Chittagong Hill Tracts. Five different sites were randomly selected from these locations for collecting soil samples (Figure 1). There were variable numbers of sites in the locations depending on the orchard cultivations and variability of slope and soil conditions. A brief description of the sites is as follows:

Site 1: Shapchari: Shapchari is located in Rangmati district at the geographical position of $22^{\circ} 40^{\prime} 41^{\prime \prime} \mathrm{N}$ and $92^{\circ} 07^{\prime} 13^{\prime \prime} \mathrm{E}$. This is a hilly area having 20-26 \% slope and an elevation of $110 \mathrm{~m}$ on the north-east aspect. The numbers of mango plants were about 1100 in the orchard of this site.

Site 2: Waggaboraichari: Waggaboraichari is located at Kaptai in Rangamati district at the geographical position of $22^{\circ} 31^{\prime \prime} 592^{\prime \prime} \mathrm{N}$ and $92^{\circ} 07^{\prime} 728^{\prime \prime}$. This is a hilly area having $15-30 \%$ slope and an elevation of $55 \mathrm{~m}$ on the north- west aspect.

Site 3: Kheikhongpara: Kheikhongpara is located in Bandarban district at the geographical position of $22^{0} 12^{\prime} 272^{\prime \prime} \mathrm{N}$ and $92^{\circ} 16^{\prime} 190^{\prime \prime} \mathrm{E}$. This is a hilly area having 5-22\% slope and an elevation of $14 \mathrm{~m}$ on the east aspect. 
SOIL FERTILITY STATUS OF SOME MANGO ORCHARDS IN CHITTAGONG HILL TRACTS

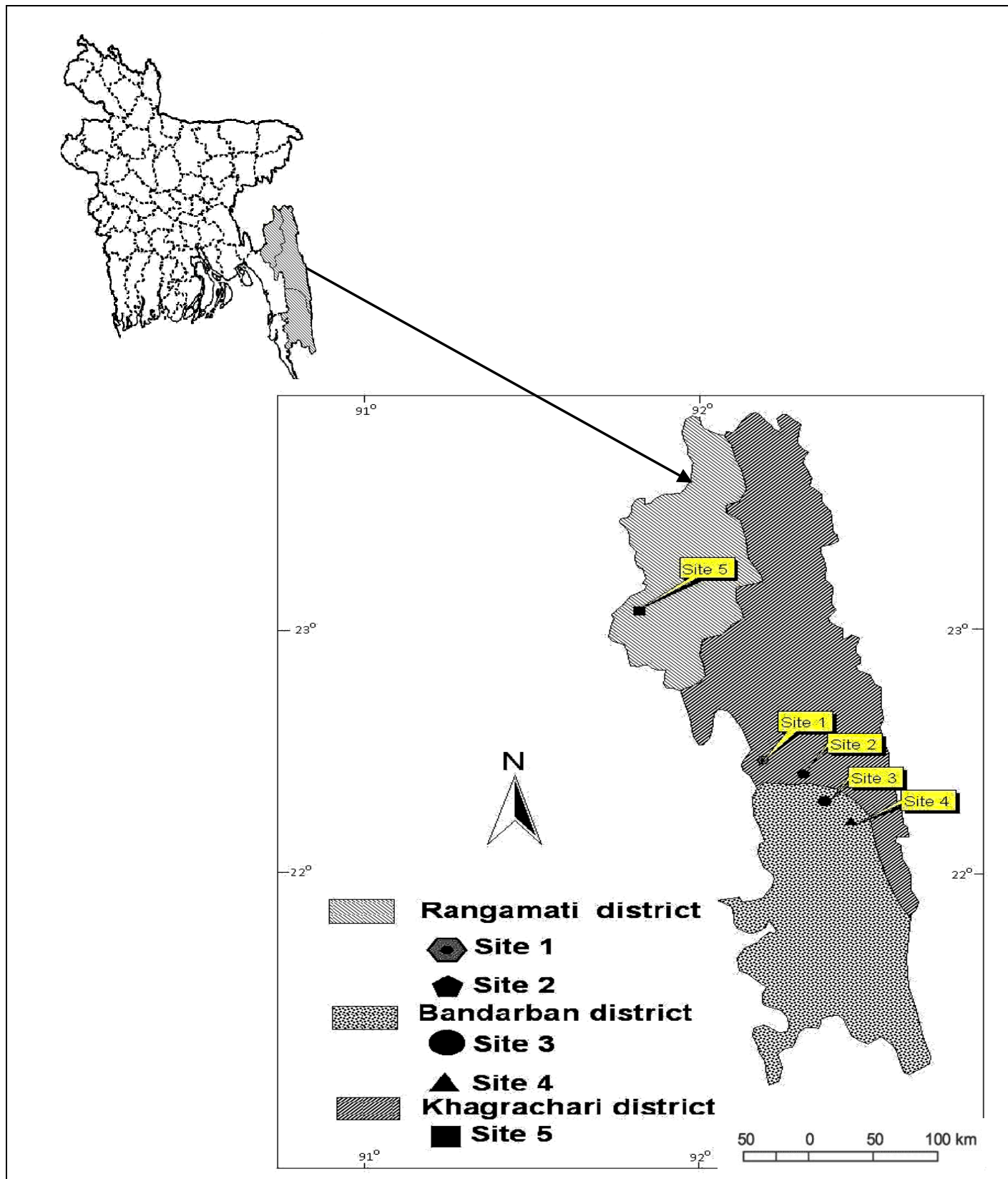

FIGURE 1: SAMPLING SITES OF THE STUDY AREA.

Source: Base map collected from CDA 2012 
KIBRIA et. al.

Site 4: Getsimonipara: Getsimonipara is located in Bandarban district at the geographical position of $22^{\circ} 11^{\prime} 605^{\prime \prime} \mathrm{N}$ and $92^{\circ} 14^{\prime} 380^{\prime \prime} \mathrm{E}$. This is a hilly area having 5-35\% slope and an elevation of $14 \mathrm{~m}$ on the east aspect. There were about 2500 mango plants.

Site 5: Parachara: Parachara is located in Khagrachari district at the geographical position of $23^{\circ} 10^{\prime} 166^{\prime \prime} \mathrm{N}$ and $91^{0} 56^{\prime} 508^{\prime \prime} \mathrm{E}$. This is a hilly area having 5-25\% slope and an elevation of $115 \mathrm{~m}$ on the north-east aspect.

\section{Soil sampling and Analysis}

Soil samples were collected from three surface positions in each site. Samples were obtained from the hill top, mid-slope and foot hill of each site, taken in polythene bags, marked well and carried to the laboratory to assess physico-chemical properties and nutrient concentrations. Particle size distribution and soil textural classes were determined by hydrometer method (Day 1965). Soil $\mathrm{pH}$ was measured by an electronic $\mathrm{pH}$ meter from a soil-water suspension at a ratio of 1:2.5. Organic carbon was determined by wet-oxidation method of Walkley and Black (1934). Total nitrogen was determined by micro-Kjeldahl digestion and distillation method (Jackson 1973). Available phosphorus was determined from field moist soils spectrophotometrically. Available phosphorus was extracted by ammonium fluoride-hydrochloric acid (Bray \& Kurtz 2) and determined according to the ascorbic acid blue color method (Murphy \& Riley 1962). $1 \mathrm{~N} \mathrm{NH}_{4} \mathrm{OAc}$ extractable potassium, calcium and magnesium were determined by an atomic absorption spectrophotometer.

\section{Statistical Analysis}

Analysis of variance and Duncan's Multiple Range Test were done using statistical software Excel (Excel Inc. 2003) and SPSS version 12 (SPSS Inc. 2003).

\section{RESULTS AND DISCUSSION}

The percentage of sand, silt and clay in mango orchard soil varied from 74 to 84,4 to 13 , and 12 to $16 \%$ respectively. Soils were sandy loam in texture at all the sites except foot hill soil of Shapchari.

Soil $\mathrm{pH}$ varied from 4.76 to 5.58 (Table 1). The highest soil $\mathrm{pH}$ was observed at Waggaboraichari and the lowest at Shapchari site. Soil $\mathrm{pH}$ varied significantly among the most sites. $\mathrm{pH}$ among the soil slope positions showed 
SOIL FERTILITY STATUS OF SOME MANGO ORCHARDS IN CHITTAGONG HILL TRACTS

significant variation at Shapchari and Getsimonipara while not at Waggaboraichari, Kheikhongpara and Parachara (Table 3). pH was significantly lower in hill top soil than in mid-slope and foot hill soil at Shapchari,. On the other hand, $\mathrm{pH}$ of the hill top soil was significantly higher than that of mid-slope and foot hill soil at Getsimonipara.

Mean organic matter content of surface soil varied significantly from 1.43 to $2.49 \%$ in different sites (Table 1). The highest soil organic matter content was observed at Gatsimonipara and the lowest soil organic matter content was found at Kheikhongpara. Organic matter content of surface soil significantly varied among the slope positions also except at Kheikhongpara (Table 2). Soil organic matter of foot hill was significantly lower than that of mid slope and top hill at Shapchari and Waggaboraichari. On the other hand, soil organic matter of foot hill was significantly higher than that of mid slope and top hill at Getsimonipara and Parachara.

Mean total nitrogen ranged from 0.10 to $0.16 \%$ in surface soil different sites (Table 2). Total $\mathrm{N}$ content of surface was significantly different among the sites. The highest total $\mathrm{N}$ content was observed at Gatsimonipara and the lowest total $\mathrm{N}$ content was found at Kheikhongpara. Total $\mathrm{N}$ content of surface soil significantly varied among the slop position at Shapchari and Parachara (Table 2). Surface soil contained higher amounts of total $\mathrm{N}$ in hill top than in mid-slope and foot hill at Shapchari. On the other hand, it contained higher amounts of total $\mathrm{N}$ in foot hill than in hill top and mid-slope at Parachara.

It can be seen from Table 1 that mean available $\mathrm{P}$ content of soils of different sites of mango orchard ranged from $0.86 \mathrm{mg} \mathrm{kg}^{-1}$ to $2.69 \mathrm{mg} \mathrm{kg}^{-1}$. The highest available $\mathrm{P}$ concentration in soil was observed at Waggaboraichari that was statistically similar to that of Gatsimonipara, Parachara and Shapchari. Among the slope position, available $\mathrm{P}$ varied significantly at all the sites (Table 2 ). Generally, the highest available $\mathrm{P}$ was found in foot hill soils at most of the sites.

$1 \mathrm{~N} \mathrm{NH}_{4} \mathrm{OAc}$ extractable $\mathrm{K}^{+}$in soils of different sites of mango orchard varied from 0.35 to $0.82 \mathrm{cmol} \mathrm{kg}^{-1}$ (Table 1). $1 \mathrm{~N} \mathrm{NH}_{4} \mathrm{OAc}$ extractable $\mathrm{K}^{+}$in surface soil was 
KIBRIA et. al.

TABLE 1. CHEMICAL PROPERTIES OF MANGO ORCHARD SOILS IN SOME SITES OF CHITTAGONG HILL TRACTS

\begin{tabular}{|c|c|c|c|c|c|c|c|}
\hline \multirow[t]{2}{*}{ Site } & \multirow[t]{2}{*}{$\mathrm{pH}$} & \multirow{2}{*}{$\begin{array}{l}\text { Organic } \\
\text { matter } \\
(\%)\end{array}$} & \multirow[t]{2}{*}{$\begin{array}{l}\text { Total N } \\
(\%)\end{array}$} & \multirow[t]{2}{*}{$\begin{array}{l}\text { Available P } \\
\left(\mathrm{mgkg}^{-1}\right)\end{array}$} & \multicolumn{3}{|c|}{$\begin{array}{l}1 \mathrm{NH}_{4} \mathrm{OAc} \text { Extractable cation } \\
\left(\mathrm{cmol} \mathrm{kg}^{-1}\right)\end{array}$} \\
\hline & & & & & $\mathrm{K}^{+}$ & $\mathrm{Ca}^{2+}$ & $\mathrm{Mg}^{2+}$ \\
\hline Shapchari & $\begin{array}{l}4.76 \\
\text { c }\end{array}$ & $1.70 \mathrm{c}$ & $0.11 \mathrm{~d}$ & $1.52 \mathrm{ab}$ & $0.50 \mathrm{bc}$ & $2.50 \mathrm{c}$ & $1.18 \mathrm{~b}$ \\
\hline Waggaboraichari & $\begin{array}{l}5.58 \\
\mathrm{a}\end{array}$ & $2.05 \mathrm{~b}$ & $0.15 \mathrm{~b}$ & $2.69 \mathrm{a}$ & $0.82 \mathrm{a}$ & $3.66 \mathrm{a}$ & $1.57 \mathrm{a}$ \\
\hline Kheikhongpara & $\begin{array}{l}5.29 \\
b\end{array}$ & $1.43 \mathrm{~d}$ & $0.10 \mathrm{e}$ & $0.86 \mathrm{~b}$ & $0.50 \mathrm{bc}$ & $3.08 \mathrm{~b}$ & $1.18 \mathrm{~b}$ \\
\hline Gatsimonipara & $\begin{array}{l}5.20 \\
b\end{array}$ & $2.49 \mathrm{a}$ & $0.16 \mathrm{a}$ & $2.67 \mathrm{a}$ & $0.66 \mathrm{ab}$ & $2.15 \mathrm{~d}$ & $1.39 \mathrm{ab}$ \\
\hline Parachara & $\begin{array}{l}5.13 \\
b\end{array}$ & $1.98 \mathrm{~b}$ & $0.13 \mathrm{c}$ & $1.81 \mathrm{ab}$ & $0.35 \mathrm{c}$ & $2.22 \mathrm{~cd}$ & $0.60 \mathrm{c}$ \\
\hline
\end{tabular}

Figures in the column having the same letter (s) did not differ significantly according to $\mathrm{DMRT} \leq 0.05$. Each value is a mean of three values of three slop positions. 
SOIL FERTILITY STATUS OF SOME MANGO ORCHARDS IN CHITTAGONG HILL TRACTS

TABLE 2. CHEMICAL PROPERTIES OF MANGO ORCHARD SOILS IN DIFFERENT SLOPES OF SOME SITES OF CHITTAGONG HILL TRACTS

\begin{tabular}{|c|c|c|c|c|c|c|c|c|c|}
\hline \multirow[b]{2}{*}{ Site } & \multirow[b]{2}{*}{$\begin{array}{c}\text { Slop } \\
\text { position }\end{array}$} & \multirow[b]{2}{*}{ Slope } & \multirow[b]{2}{*}{$\mathrm{pH}$} & \multirow[b]{2}{*}{$\begin{array}{l}\text { Organic matter } \\
(\%)\end{array}$} & \multirow[b]{2}{*}{$\begin{array}{l}\text { Total N } \\
(\%)\end{array}$} & \multirow[b]{2}{*}{$\begin{array}{l}\text { Available P } \\
\left(\mathrm{mgkg}^{-1}\right)\end{array}$} & \multicolumn{3}{|c|}{$1 \mathrm{NH}_{4} \mathrm{OAc}$ Extractable cation $\left(\mathrm{cmol} \mathrm{kg}^{-1}\right)$} \\
\hline & & & & & & & $\mathrm{K}^{+}$ & $\mathrm{Ca}^{2+}$ & $\mathrm{Mg}^{2+}$ \\
\hline \multirow{3}{*}{ Shapchari } & Top & $20^{\circ}$ & $4.61 \mathrm{~b}$ & $2.03 \mathrm{a}$ & $0.13 \mathrm{a}$ & $2.76 \mathrm{a}$ & $0.25 \mathrm{~b}$ & $2.50 \mathrm{~b}$ & $1.25 \mathrm{~b}$ \\
\hline & Middle & $26^{\circ}$ & $4.87 \mathrm{a}$ & $1.58 \mathrm{~b}$ & $0.11 \mathrm{~b}$ & $1.78 \mathrm{~b}$ & $0.28 \mathrm{~b}$ & $2.71 \mathrm{a}$ & $1.50 \mathrm{a}$ \\
\hline & Valley & $23^{\circ}$ & $4.80 \mathrm{a}$ & $1.50 \mathrm{c}$ & $0.10 \mathrm{~b}$ & $0.03 \mathrm{c}$ & $0.96 \mathrm{a}$ & $2.25 \mathrm{c}$ & $0.79 \mathrm{c}$ \\
\hline \multirow{3}{*}{ Waggaboraichari } & Top & $27^{\circ}$ & $5.50 \mathrm{a}$ & $2.15 \mathrm{a}$ & $0.15 \mathrm{a}$ & $2.40 \mathrm{~b}$ & $0.89 \mathrm{~b}$ & $3.50 \mathrm{~b}$ & $1.75 \mathrm{a}$ \\
\hline & Middle & $30^{\circ}$ & $5.47 \mathrm{a}$ & $2.12 \mathrm{a}$ & $0.15 \mathrm{a}$ & $1.81 \mathrm{c}$ & $0.59 \mathrm{c}$ & $3.74 \mathrm{a}$ & $1.72 \mathrm{a}$ \\
\hline & Valley & $15^{\circ}$ & $5.77 \mathrm{a}$ & $1.89 \mathrm{~b}$ & $0.14 \mathrm{a}$ & $3.87 \mathrm{a}$ & $0.98 \mathrm{a}$ & $3.75 \mathrm{a}$ & $1.25 \mathrm{~b}$ \\
\hline \multirow{3}{*}{ Kheikhongpara } & Top & $5^{\circ}$ & $5.50 \mathrm{a}$ & $1.41 \mathrm{a}$ & $0.10 \mathrm{a}$ & $0.67 \mathrm{c}$ & $0.73 \mathrm{a}$ & $3.50 \mathrm{a}$ & $1.18 \mathrm{~b}$ \\
\hline & Middle & $6^{\circ}$ & $5.17 \mathrm{a}$ & $1.41 \mathrm{a}$ & $0.09 \mathrm{a}$ & $0.77 \mathrm{~b}$ & $0.46 \mathrm{~b}$ & $2.25 \mathrm{~b}$ & $1.25 \mathrm{a}$ \\
\hline & Valley & $22^{\circ}$ & $5.20 \mathrm{a}$ & $1.46 \mathrm{a}$ & $0.10 \mathrm{a}$ & $1.14 \mathrm{a}$ & $0.30 \mathrm{c}$ & $3.50 \mathrm{a}$ & $1.10 \mathrm{c}$ \\
\hline \multirow{3}{*}{ Gatsimonipara } & Top & $5^{\circ}$ & $5.50 \mathrm{a}$ & $2.48 \mathrm{~b}$ & $0.17 \mathrm{a}$ & $3.41 \mathrm{~b}$ & $0.95 \mathrm{a}$ & $2.25 \mathrm{a}$ & $1.75 \mathrm{a}$ \\
\hline & Middle & $30^{\circ}$ & $5.00 \mathrm{~b}$ & $2.17 \mathrm{c}$ & $0.16 \mathrm{a}$ & $1.14 \mathrm{c}$ & $0.45 \mathrm{c}$ & $1.95 \mathrm{~b}$ & $0.93 \mathrm{c}$ \\
\hline & Valley & $35^{\circ}$ & $5.10 \mathrm{~b}$ & $2.82 \mathrm{a}$ & $0.16 \mathrm{a}$ & $3.46 \mathrm{a}$ & $0.59 \mathrm{~b}$ & $2.25 \mathrm{a}$ & $1.50 \mathrm{~b}$ \\
\hline \multirow[b]{3}{*}{ Parachara } & Top & $5^{\circ}$ & $5.20 \mathrm{a}$ & $1.89 \mathrm{~b}$ & $0.12 \mathrm{~b}$ & $0.45 \mathrm{~b}$ & $0.34 \mathrm{~b}$ & $2.25 \mathrm{~b}$ & $0.49 \mathrm{~b}$ \\
\hline & Middle & $7^{\circ}$ & $5.10 \mathrm{a}$ & $1.89 \mathrm{~b}$ & $0.12 \mathrm{~b}$ & $0.26 \mathrm{c}$ & $0.30 \mathrm{c}$ & $1.92 \mathrm{c}$ & $0.69 \mathrm{a}$ \\
\hline & Valley & $25^{\circ}$ & $5.10 \mathrm{a}$ & $2.17 \mathrm{a}$ & $0.15 \mathrm{a}$ & $4.63 \mathrm{a}$ & $0.42 \mathrm{a}$ & $2.50 \mathrm{a}$ & $0.63 \mathrm{a}$ \\
\hline
\end{tabular}

Figures in the column having the same letter (s) within a location did not differ significantly according to DMRT $\leq 0.05$. 
significantly different among the sites. The highest $\mathrm{K}^{+}$content of soil was observed at Waggaboraichari and the lowest $\mathrm{K}^{+}$content was found at Parachara. $1 \mathrm{~N} \mathrm{NH}_{4} \mathrm{OAc}$ extractable $\mathrm{K}^{+}$in surface soil significantly varied among the slope position also (Table 2). It was significantly higher in hill top than in mid-slope and foot hill soil at Kheikhongpara and Gatsimonipara. At Shapchari, Waggaboraichari and Parachara, its content was significantly higher in foot hill than in hill top and mid-slope soil.

$1 \mathrm{~N} \mathrm{NH}_{4} \mathrm{OAc}$ extractable $\mathrm{Ca}^{2+}$ varied from 2.50 to $3.66 \mathrm{cmol} \mathrm{kg}^{-1}$ in the surface soils of different sites of mango orchard (Table 1). A significant variation in $1 \mathrm{~N} \mathrm{NH}_{4} \mathrm{OAc}$ extractable $\mathrm{Ca}^{2+}$ was found among the sites. The highest NH4OAc extractable $\mathrm{Ca}^{2+}$ content of soil was observed at Waggaboraichari and the lowest $\mathrm{Ca}^{2+}$ content was found at Gatsimonipara. $1 \mathrm{~N} \mathrm{NH} \mathrm{NH}_{4} \mathrm{OAc}$ extractable $\mathrm{Ca}^{2+}$ in soil significantly varied among the slope position at all the sites. However, there was no definite trend of variation in $\mathrm{Ca}^{2+}$ content among the sites (Table 2).

Mean $1 \mathrm{~N} \mathrm{NH}_{4} \mathrm{OAc}$ extractable $\mathrm{Mg}^{2+}$ ranged from 0.60 to $1.57 \mathrm{cmol} \mathrm{kg}^{-1}$ in the surface soils of different sites of mango orchard (Table 1). The highest $\mathrm{NH}_{4} \mathrm{OAc}$ extractable $\mathrm{Mg}^{2+}$ was found at Waggaboraichari and the lowest $1 \mathrm{~N}$ $\mathrm{NH}_{4} \mathrm{OAc}$ extractable $\mathrm{Mg}^{2+}$ was found at Parachara. $1 \mathrm{~N} \mathrm{NH}_{4} \mathrm{OAc}$ extractable $\mathrm{Mg}^{2+}$ varied significantly among the sites of mango orchard. However, there was no definite trend of variation in $\mathrm{Mg}^{2+}$ among the slope position (Table 2).

Mango is being planted in increasingly large scales on slightly to steeply sloping deforested hilly lands with shallow to moderately deep well drained soils of hill districts of Bangladesh. The fertility status of the soils has not been sufficiently evaluated. There have been few studies earlier on suitability of the existing soils for different fruit orchards. These plant species have originated in tropical regions with monsoon climate. So, if the soils are suitable, there should be satisfactory performance of the fruit plants. The deforested and somewhat degraded lands would profitably be utilized.

Mango has adapted to a wide variety of soil types, including red or yellow Latosols, Quartz Neosols (sandy quartz) and Argisols (Podzols) of low fertility. However, its growth and production are influenced by the physical and chemical characteristics of the soil. It grows best in soils deeper than $>2 \mathrm{~m}$, which are well drained and without salinity problems. Unsuitable soil characteristics include shallow soils less than one meter in depth and those with sub-soils having rocks or too sticky as clay (ASB, 2006). Depth of soil in some localities of Chittagong might be a limitation because soils originating from Tipam/Surma formations may 
SOIL FERTILITY STATUS OF SOME MANGO ORCHARDS IN CHITTAGONG HILL TRACTS

underlie hard rock or plinthitic concretions at a depth close to the surface. Such lands should be avoided during selecting sites for orchards. Mangoes prefer well drained, light textured soils (sands, sandy loams, loams, sandy clay loams, and sandy clays). The soils most recommended are sandy clays, rich in organic matter that are deep and flat (Magalhaes and Borges 2000). However, rich, medium and well drained soils give better results.

Mango growing soils range in $\mathrm{pH}$ from 5.5 to 7.5 , but it grows well in soils with slightly acidic $\mathrm{pH}$. In extreme ranges of soil $\mathrm{pH}$, some nutrient elements become unavailable to the plant even though there may be adequate or even high levels of these elements in the soil. Optimum soil $\mathrm{pH}$ is $6.5-7.0$, and optimum nutrients are $70 \mathrm{mg} \mathrm{kg}^{-1} \mathrm{P}, 100-150 \mathrm{mg} \mathrm{kg}^{-1} \mathrm{~K}, 600-1000 \mathrm{mg} \mathrm{kg}^{-1} \mathrm{Ca}$ and $90-150$ $\mathrm{mg} \mathrm{kg}^{-1} \mathrm{Mg}$ (Poffley and Owens 2005). According to classification of soils on the basis of soil reaction (BARC 2005), the studied soils are strongly to moderately acid. The soils are generally poor in organic matter and nutrients. The organic matter status has been classified as: very low (1\%); low (1.1-1.7\%); medium (1.73.4); high (3.4-5.5); and very high >5.5 (BARC 2005). However, some of the presently studied soils had organic matter around $2 \%$. Such organic matter content might have developed from the luxuriant past forest vegetation. The variation in $\mathrm{N}$ contents might be due to number of reasons such as differences in natural fertility, variation in cultural practices, variation in the $\mathrm{N}$ applied fertilizers. According to the quantitative standards suggested by Jackson (1973), for soil $\mathrm{N}$ all soils are high in total $\mathrm{N}$ contents. Similar to $\mathrm{N}$, there was much variation in soil available $\mathrm{P}$. The available phosphorus in Bangladesh soils could be considered between low and medium (BARC 2005). In the present study, available P content of the soils was in the low range in all the sites. On the basis of standards for $\mathrm{P}$ (deficient $<3.0 \mathrm{mg} \mathrm{kg}^{-1}$, low range $3.0-4.0 \mathrm{mg} \mathrm{kg}^{-1}$, satisfactory range $5.0-7.0 \mathrm{mg}$ $\mathrm{kg}^{-1}$ and high range $>8.0 \mathrm{mg} \mathrm{kg}^{-1}$ ) laid down by Watanabe and Olsen (1965), most of the soils were deficient in and some had low level of available P. Only $12 \%$ of the soils had sufficient available $\mathrm{P}$ for normal plant growth. About $0.12 \mathrm{cmol} \mathrm{kg}^{-1}$ of $\mathrm{NH}_{4} \mathrm{OAc}$ extractable $\mathrm{K}$ is considered the critical limit for Bangladesh soils. The present exchangeable $\mathrm{K}$ values are mostly above the critical level. Performance of mango in some sites is not satisfactory particularly where soil $\mathrm{pH}$ is low $(<5.0)$. Corrective liming is required in acidic soils to increase soil $\mathrm{pH}$ to $6.0-6.5$, the best range for mango, and also to increase the base saturation to 60-70\% (Pinto 2000). Liming is especially recommended when there are acidic sub soils with aluminium saturation $>20 \%$ and $\mathrm{Ca}<0.5 \mathrm{cmol} \mathrm{c} \mathrm{dm}^{-3}$ in any soil layer up to $60 \mathrm{~cm}$ deep (Andrade 2004). 
KIBRIA et. al.

From the forgoing discussion it may be concluded that the soils are inherently poor in fertility as high rates of organic matter and nutrient depletion occur due to shifting cultivation. A long term fertility management program and monitoring are urgently needed for sustainability of mango orchards in the areas. Conservation tillage and cover crop management for eroded soil surface will be effective. The findings of the present research work may give an indication of the future planning and program in the management of mango orchards of Chittagong Hill Tracts.

\section{REFERENCES}

ANDRADE, L.R.M. 2004. Corretivos e fertilizantes para culturas perenes e semiperenes. In: Cerrado, correção do solo e adubação (D.M.G. Sousa, and E. Lobato ed.). Embrapa Informação Tecnológica, Brasilia, pp. 317-366.

ASB (Asiatic Society of Bangladesh). 2006. BANGLAPEDIA. Asiatic Society of Bangladesh, Dhaka.

BBS. 2009. Statistical Year Book of Bangladesh, 2008. Bangladeshg Bureau of Statistics, Ministry of Planning, Govt. of the People's Republic of Bangladesh, Dhaka, 586pp.

BARC (Bangladesh Agricultural Research Council). 2005. Fertilizer Recommendation Guide for Most Bangladesh Crops. Publication 53. BARC, Dhaka, 270 pp

DAY, P. R. 1965. Particle fractionation and particle size analysis.. In: Methods of Soil Analysis. (C. A. Black ed.). Part I. Agronomy Monograph, Academic Press, New York, pp. 545-567

EXCEL INC. 2003. Microsoft Excel for Windows, Microsoft Corporation.

GAUTAM, I. P., THAPA, M. P. AND GUPTA, K. P. 2004. Cultivar Evaluation on Mango in Low Hills of Eastern Nepal. Nepal Net: An Electronic Networking for Sustainable Development in Nepal. National Agricultural Research Center, Nepal.

JACKSON, M L. 1973. Soil Chemical Analysis. Prentice Hall of India Private Limited, New Delhi, India. 498pp.

KHISA, S. K. 1997. Indigenous Technology/Knowledge of Watershed Management in the Culture of Ethnic Communities of Chittagong Hill Tracts. Paper Presented at the National Workshop on Indigenous Technology/ Knowledge in Watershed Management held at Bangladesh Forest Academy, Chittagong from 30th November-3rd December 1997. P. 12. 
SOIL FERTILITY STATUS OF SOME MANGO ORCHARDS IN CHITTAGONG HILL TRACTS

MAGAlHÃES, A. F. de J. AND BORGES, A. L. 2000. Calagem e adubação. Manga produção aspectos técnicos. Embrapa Comunicação para Transferência de Tecnologia, Brasília. 69 pp

MARSCHNER, H. 1995. Mineral nutrition of higher plants. 2nd Ed. Academic press, London UK. 889pp.

Murphy, J. AND Riley, J. P. 1962. A modified single solution method for the determination of phosphate in natural waters. Anal. Chim. Acta. 27: 31-36.

PINTO, A. C. de Q. 2000. A teorática no cultivo da manga: sinopse. Embrapa Cerrados, Planaltina, Brasilia. 39 pp

POFFLEY, M. AND OWENS, G. 2005. Mango leaf and soil analysis. Agnote; Agdex No.: 234/10; p 1-4.

SPSS INC. 2003. Statistics. SPSS Inc. Chicago.

WALKLEY, A. AND BLACK, I.A. 1934. An examination of the Degtjareff method for determining organic carbon in soils: Effect of variations in digestion conditions and of inorganic soil constituents. Soil Sci. 63:251-263.

WATANABE, F. S. AND OLSEN, S. R.1965. Test of an ascorbic acid method of determining phosphorus in water and $\mathrm{NaHCO}_{3}$ extracts from soil. Soil Sci. Soc. Am. Proc, 29: 677-678

Manuscript received on 28.05.2012; Accepted on 07.07.2012

The Chittagong University Journal of Biological Sciences, Vol. $6(1 \& 2)$. Page No. 